ks. Piotr Ryguła

\title{
Kryteria dopuszczenia dzieci do pierwszej komunii św.
}

Możliwość uczestnictwa w Eucharystii i przyjęcia komunii św. regulują w Kodeksie prawa kanonicznego z 1983 roku kan. 912-923 współtworzące razem jeden corpus normatywny artykułu 2 zatytułowanego Uczestnictwo w Najświętszej Eucharystii'. W pierwszym z wspomnianych kanonów prawodawca kościelny stwierdza: „Każdy ochrzczony, jeśli tylko prawo tego nie zabrania, może i powinien być dopuszczony do Komunii świętej”2. W ten sposób formułuje on podstawowe prawo ochrzczonego do przystępowania do komunii św., mieszczące się w ramach szerzej ujętego prawa wiernych do otrzymywania pomocy „od swoich pasterzy z duchowych dóbr Kościoła, zwłaszcza zaś słowa Bożego i sakramentów”3.

Prawo ochrzczonego zdefiniowane w kan. 912 nie jest jednak nieograniczone. Kodeks ogranicza to prawo ze względu na brak dyspozycji u przyjmującego komunię św. (kan. 913 i 914), popadnięcie w kary kościelne i brak pełnej jedności z Kościołem

1 Chodzi o artykuł 2 (Uczestnictwo w Najświętszej Eucharystii) rozdziału I (Sprawowanie Eucharystii) w tytule III (Najświętsza Eucharystia) księgi IV (Uświęcające zadanie Kościoła) Kodeksu prawa kanonicznego z 1983 roku [dalej: KPK 1983].

2 KPK 1983, kan. 912.

3 KPK 1983, kan. 213. 
katolickim (kan. 96 i 915). Należy przy tym pamiętać, że zgodnie z kan. 18 KPK z 1983 roku przepisy ustawy kościelnej ograniczającej swobodne wykonywanie uprawnień podlegają interpretacji ścisłej ${ }^{4}$.

Przedmiotem niniejszego opracowania są kryteria dopuszczenia dzieci do pierwszej komunii św., regulowane przez obecnie obowiązujący kodeks w kan. 912-914. Pierwszy z kanonów, cytowany powyżej, wyraża fundamentalne prawo każdego ochrzczonego do udzielania mu komunii św. Pozostałe regulują dwie kwestie: przygotowanie do pierwszego w życiu przyjęcia komunii św. i kryteria, które powinna spełniać osoba przyjmująca.

Przed analizą pozostających obecnie w mocy przepisów kodeksowych omówione zostaną historyczne źródła istniejących dzisiaj kryteriów. Łacińska formuła „ex nihilo nihil fit”s ma bowiem swoje zastosowanie także w prawie. Zasadę tę, głoszącą przekonanie, że „z niczego nic nie powstaje” w starożytności pojmowano bowiem jako „zasadę wszystkich zasad” i aplikowano do wyjaśnienia powstania rzeczy. Stosowanie wspomnianej zasady implikowało pojmowanie powołania do istnienia konkretnego bytu jako compositio/generatio w znaczeniu mutatio lub też jako corruptio w stosunku do bytu wcześniej istniejącego. Prawidłowość ta zastosowana z perspektywy historii prawa podpowiada, że regulacje obecnie obowiązujące nie wzięły się z niczego, ale zakorzenione są w konkretnej tradycji, stanowiąc jej rozwinięcie, rzadziej reakcję dążącą do zmiany czy nawet odwrócenia

4 Por. E. Górecki, Najświętsza Eucharystia, w: W. Góralski, E. Górecki, J. Krukowski, J. Krzywda, P. Majer, B. Zubert, Komentarz do Kodeksu prawa kanonicznego, t. III/2: Uświęcające zadanie Kościoła. Część I: Sakramenty. Część II: Pozostałe akty kultu Bożego. Część III: Miejsca i czasy święte, Poznań 2010, s. 98.

5 Łacińska formuła „ex nihilo nihil fit” (z niczego nic nie powstaje) sformułowana została przez eleatów (Melissos z Samos), a dotarła do naszych czasów za pośrednictwem dzieła Lukrecjusza $O$ naturze wszechrzeczy. 
istniejącego w danym momencie kierunku legislacji. Rzeczona prawidłowość sprawdza się m.in. odniesieniu do historii legislacji kanonicznej w zakresie kryteriów regulujących dopuszczenie dzieci do pierwszej komunii św.

\section{Przyjmowanie komunii św. do XII wieku}

Jak już wspomniano, podstawowym kryterium dopuszczenia do przyjęcia komunii św. jest wcześniejsze przyjęcie chrztu. Zasada ta zakorzeniona jest w pierwotnym chrześcijaństwie, o czym świadczy m.in. zaliczany do pism apostolskich tekst Didache (Nauki Dwunastu Apostołów), w którym zezwala się na spożywanie pokarmu eucharystycznego w czasie Wieczerzy Pańskiej tylko osobom ochrzczonym ${ }^{6}$. Podobnie św. Justyn, apologeta i męczennik żyjący na początku II wieku pisze: „Pokarm ów nazywa się u nas Eucharystią; może go zaś spożywać jedynie ten, kto wierzy w prawdziwość naszej nauki, a ponadto został obmyty z grzechów i odrodzony oraz żyje według przykazań Chrystusa. W naszym bowiem przekonaniu nie jest to zwyczajny chleb i napój"7. Oba wspomniane wyżej teksty mówią o konieczności chrztu św. przed przyjęciem po raz pierwszy w życiu komunii św.

Od pierwszych wieków chrześcijaństwa obrzęd chrztu połączony był z udzielaniem neofitom pierwszej w ich życiu komunii św. Praktyka taka do XII wieku dotyczyła nie tylko dorosłych, ale także dzieci. Najstarsze świadectwa historyczne podpowiadające istnienie takiej praktyki pochodzą z III wieku', zaś od v do

6 Zob. Didache IX, 5. Polski tekst Didache zob.: Didache, czyli Nauka Dwunastu Apostołów, przełożył z greckiego J. Jankowski z dodaniem komentarza E. Bessona, Warszawa 1923.

7 Polski tekst Apologii św. Justyna cytowany za: M. Michalski, Antologia literatury patrystycznej, t. 1, Warszawa 1975, s. 97.

8 W Tradycji apostolskiej św. Hipolita mowa jest o chrzcie (c. 20) i o następującym zaraz potem obrzędzie namaszczenia i Eucharystii (c. 21). W c. 20 zaleca się, 
XII stulecia rzeczona praktyka jest bezsprzecznie dowiedziona przez licznie zachowane źródła ${ }^{9}$. O komunii św. dzieci przyjmowanej po chrzcie św. w v wieku pisali św. Paulin z Noli i Genadiusz z Marsylii. Pierwszy z nich pisał o kapłanie, który prowadzi dzieci od świętego źródła do ołtarza i tam karmi je „zbawiennym pokarmem"”; drugi - opisuje obrzędy chrztu dzieci, po których dopuszcza się je do bierzmowania, a następnie do tajemnic eucharystycznych"1. Żyjący w IX wieku Magnus z Sens pisze o spożywaniu Ciała i Krwi Pańskiej bezpośrednio po odrodzeniu z wody i z Ducha Świętego ${ }^{12}$. Dwunastowieczny autor Radulfus Ardens w homilii wielkanocnej wspomina o podawaniu dzieciom komunii św. zaraz po chrzcie św., aby nie umarły bez koniecznego sakramentu' ${ }^{13}$. Kolejny dwunastowieczny autor - bp Wilhelm z Champeaux odnotowuje, że małym dzieciom, które nie potrafią jeszcze przyjąć Chrystusa pod postacią chleba, po chrzcie podaje się Kielich z krwią Pańską¹

aby chrzest rozpocząć od dzieci, w c. 21 natomiast, gdy mowa jest o czynnościach związanych z udzielaniem komunii św. nowo ochrzczonym, stwierdza się „Tak winno się sprawować to przy każdym” (H. Paprocki, Hipolita Rzymskiego „Tradycja Apostolska”: wstęp przekład komentarz, „Studia Theologica Varsaviensia” 14 (1976) $\mathrm{nr}$ 1, s. 160). Na temat tekstów św. Cypriana w kwestii komunii św. niemowląt i konieczności Eucharystii do zbawienia oraz nauki św. Augustyna o zbawczej konieczności komunii niemowląt zob. J. Salij, Główne kontrowersje teologiczne wokót komunii niemowląt, Warszawa 1982, s. 14-19.

9 Na temat nauki św. Augustyna o zbawczej konieczności komunii niemowląt oraz problemu zbawienia ochrzczonych, którzy zmarli bez komunii św. w teologii poaugustiańskiej, zob. J. Salij, Główne kontrowersje..., dz. cyt., s. 19-51.

10 S. Paulinus Nolanus, Ep. 32, w: S. Paulini Nolani Opera omnia, tomus unicus, accurante J.-P. Migne, Parisiis 1861 (Patrologiae Cursus Completus. Series Latina [dalej: PL], 61, 333).

11 Zob. Gennadius Massiliensis, Lib. de ecclesiasticis dogmatibus, c. 52 (PL 58, 993).

12 Zob. Magnus Senonensis, Libellus de mysterio baptismatis (PL 102, 984).

13 Zob. Radulphus Ardens, Homilia LI (PL 155, 1850).

14 Zob. Guillelmus de Campellis, Notitia historica (PL 163, 1039). 
Praktyka przyjmowania komunii św. przez małe dzieci nie tylko bezpośrednio po chrzcie św., ale także i w kolejnych latach dzieciństwa istniała do XII wieku' ${ }^{15}$, zarówno w Kościele na Zachodzie, jak i na Wschodzie. Małym dzieciom Komunię podawano pod postacią wina, starszym pod dwoma postaciami ${ }^{16}$.

Od XII wieku na Zachodzie zaczęły pojawiać się jednak opinie nieprzychylne dotychczasowej praktyce, szczególnie w stosunku do niemowląt. Podkreślano, że do pełnej skuteczności sakramentu potrzeba osobistego współdziałania z łaską, o co trudno u tak małych dzieci. Coraz wyraźniej dostrzegano też konieczność życia zgodnego z zasadami Ewangelii nie tylko w przypadku dorosłych, którzy przyjmują Eucharystię, ale także w przypadku dzieci ${ }^{17}$.

W odniesieniu do dorosłych wspomnianą konieczność dostrzeżono dużo wcześniej. Dlatego już w wiekach II-V zaczęto odchodzić od praktyki dopuszczania neofitów do chrztu i Eucharystii w krótkim czasie po nawróceniu, poddając ich procesowi wtajemniczenia w prawdy wiary w ramach instytucji katechumenatu ${ }^{18}$. Dopiero po kilku latach przygotowań katechumeni dopuszczani byli do sakramentów wtajemniczenia chrześcijańskiego. Sakramenty te sprawowano w czasie Wigilii Paschalnej. Wówczas to katechumeni przyjmowali chrzest, następnie w znaku nałożenia na nich rąk otrzymywali dary Ducha Świętego, aby w koń$\mathrm{cu}$, zwykle o świcie w niedzielę zmartwychwstania pierwszy raz

15 Por. D. Zimoń, Uczestnictwo wiernych we mszy św. $w$ duchu liturgii na ziemiach polskich w XIX wieku, „Śląskie Studia Historyczno-Teologiczne” 11 (1978), s. 102.

16 Por. J. Szczepański, Pierwsza komunia dzieci w Kościele rzymskokatolickim w Europie Zachodniej i w Polsce, Kraków 2003, s. 29. Zob. także W. Schenk, Liturgia sakramentów świętych, cz. 1: Initiatio cristiana, Lublin 1962, s. 99.

17 Por. J. Szczepański, Pierwsza komunia..., dz. cyt., s. 30.

18 Por. Katechumenat $i$ inicjacja chrześcijańska w Kościele starożytnym, red. F. Drączkowski, J. Pałucki, P. Szczur, M. Szram, M. Wysocki, M. Ziółkowska, Lublin 2011. 
w życiu uczestniczyć w pełni w Eucharystii, przyjmując komunię św. ${ }^{19}$ Wtajemniczenie w chrześcijaństwo pojmowane było więc jako dłuższy okres, w którym wprowadzano katechumena w życie Kościoła, w tym do pełnego udziału w podstawowym dla wspólnoty chrześcijan akcie eklezjalnym, jakim jest pełne uczestnictwo w Eucharystii ${ }^{20}$.

Od v wieku charakterystyczny dla starożytnego chrześcijaństwa katechumenat zaczął jednak zanikać. Najpierw zaczęto go skracać, np. do jednego Wielkiego Postu, aby w końcu całkowicie zaprzestać jego praktykowania. Wiązało się m.in. z coraz częstszym udzielaniem chrztu nie dorosłym, lecz małym dzieciom, niejednokrotnie poza Wigilią Paschalną ${ }^{21}$, a także z rozdzieleniem w czasie udzielania chrztu, bierzmowania i komunii św. Wielowiekowa praktyka starożytnego katechumenatu utrwaliła natomiast w świadomości chrześcijan potrzebę poznania podstaw wiary przez osoby pragnące przyjąć sakramenty inicjacji chrześcijańskiej (w tym prawd dotyczących Eucharystii).

W Ordo baptismatis z x wieku stwierdza się, że celebrację chrztu i mszy św. należy od siebie oddzielić2 ${ }^{22}$. Przykład ten pokazuje wyraźnie kierunek zmian, który pod koniec pierwszego i na początku drugiego tysiąclecia doprowadził ostatecznie do sytuacji, w której sakramenty wtajemniczenia chrześcijańskiego udzielane były poszczególnym wiernym przez różnych szafarzy i w różnym

19 Por. M. Pastuszko, Prawo o sakramentach świętych, Warszawa 1983, s. 203.

20 Por. S. Czerwik, Wtajemniczenie chrześcijańskie, w: Sakramenty wtajemniczenia chrześcijańskiego, red. J. Kudasiewicz, Warszawa 1981, s. 1o. Na temat katechumenatu starożytnego zob. także: B. Mokrzycki, Katechumenat wczesnochrześcijański, „Communio” 3 (1983) nr 1, s. 9-27; M. Dujarier, Krótka historia katechumenatu, tłum. A. Świeykowska, U. Grajczak, Poznań 1990.

21 Por. M. Pastuszko, Uczestnictwo w Najświętszej Eucharystii, (kanony 912923), „Prawo Kanoniczne” 36 (1993) nr 3-4, s. 41. Zob. także: M. Szram, Przedmowa, w: Katechumenat i inicjacja chrześcijańska..., dz. cyt., s. 6.

22 Por. M. Pastuszko, Prawo o sakramentach świętych, Warszawa 1983, s. 222. 
czasie; zawsze jednak z zachowaniem zasady, że chrzest (udzielany jako pierwszy) stanowi podstawę uprawniającą do otrzymania kolejnych sakramentów ${ }^{23}$.

Praktyka podawania komunii św. małym dzieciom przetrwała do naszych czasów w niektórych Kościołach wschodnich, np. u koptów. W Kościele zachodnim zachowywano ją do XII wieku, po czym ustała na skutek zwyczaju przeciwnego, zgodnie z którym udzielenie pierwszej komunii św. odkładano do czasu dojścia przez dzieci do lat rozeznania ${ }^{24}$. Pojawiające się w XII stuleciu nowe tendencje pastoralne dotyczące kryteriów dopuszczania do pierwszej komunii św. znalazły swoje odzwierciedlenie w nauczaniu Soboru Laterańskiego IV. Sobór ten zamknął formalnie okres, w którym praktykowano komunię chrzestną, a rozpoczął trwający do dzisiaj okres, w którym pierwszej komunii św. udziela się dzieciom w tzw. wieku rozeznania.

\section{Od Soboru Laterańskiego IV do pontyfikatu Piusa $x$}

Sobór Laterański IV zwołany został przez papieża Innocentego III w 1215 roku, a uczestniczyło w nim 404 biskupów Zachodniego Kościoła Łacińskiego i Wschodniego Kościoła Katolickiego, ponad 8 oo przełożonych zakonnych, a także wysłannicy królów Anglii, Francji, Węgier, Aragonii i Portugaliii ${ }^{25}$. Wśród 71 uchwalonych na nim konstytucji, w konstytucji 21 ojcowie soborowi zobowiązali

23 Por. M. Pastuszko, Najświętsza Eucharystia według Kodeksu prawa kanonicznego Jana Pawła II, Kielce 1997, s. 139.

24 Por. M. Pastuszko, Najświętsza Eucharystia..., dz. cyt., s. 144.

25 Papież pragnął, aby zwołany przez niego sobór był na tyle, na ile to tylko możliwe reprezentatywny dla całego Kościoła, zarówno dla duchowieństwa, jak i świeckich. Był to sobór, w którym po raz pierwszy udział wziął prawie cały episkopat Europy środkowo-wschodniej, tj. episkopat polski, czeski i węgierski. Zob. J. W. O’Malley, Historia papieży, Kraków 2010, s. 166; D. Olszewski, Dzieje chrześcijaństwa w zarysie, Katowice 1983, s. 125. 
każdego wiernego do spowiedzi św. wobec własnego kapłana przynajmniej raz w roku oraz do przyjęcia komunii św. przynajmniej w czasie wielkanocnym (ad minus in Pascua). Obowiązkiem tym objęli wszystkich wiernych obojga płci, którzy doszli do „lat rozeznania" (anni discretionis) ${ }^{26}$. W ten sposób sobór potwierdzał oddzielenie chrztu od Eucharystii i bierzmowania w procesie inicjacji chrześcijańskiej ${ }^{27}$.

Wspomniana konstytucja 21, wraz z wieloma innymi postanowieniami Soboru Laterańskiego III i IV, weszła w skład promulgowanego 5 września 1234 roku zbioru Dekretałów Grzegorza $\mathrm{IX}^{28}$. Jako integralna część rzeczonego zbioru (zbioru prawa powszechnego) wspomniana konstytucja obowiązywała do 1918 roku, tj. do wejścia w życie Pio-Benedyktyńskiego Kodeksu prawa kanonicznego ${ }^{29}$. Ciesząc się powagą Soboru Laterańskiego IV, a następnie poważaniem, jakim darzono Dekretały Grzegorza IX, regulacja zawarta $\mathrm{w}$ soborowej konstytucji $21 \mathrm{w}$ szybkim czasie wyparła z Kościoła zachodniego dotychczasową praktykę komunii chrzestnej.

Przesuwając w czasie pełne uczestnictwo w Eucharystii na „lata rozeznania”, sobór słusznie powiązał z sobą przyjęcie komunii św. i spowiedź; szczególnie jeśli na myśli mamy przyjęcie komunii św. po raz pierwszy w życiu. Praktyka komunii chrzcielnej wiązała się bowiem - zarówno w wypadku małych dzieci, jak i dorosłych katechumenów - z otrzymaniem w jednym obrzędzie inicjacji

26 Tekst konstytucji 21 Soboru Laterańskiego IV zob.: Dokumenty soborów powszechnych. Tekst grecki, łaciński, polski, t. 2: (869-1312) Konstantynopol IV, Lateran I, Lateran II, Lateran III, Lateran IV, Lyon I, Lyon II, Vienne, red. A. Baron, H. Pietras, Kraków 2013, s. 259-26o.

27 M. Pastuszko, Uczestnictwo..., dz. cyt., s. 44

28 Por. I. Subera, Historia źródet i nauki prawa kanonicznego, Warszawa 1970, S. $120-125$.

29 Por. M. Pastuszko, Wielkanocna komunia święta, „Prawo Kanoniczne” 30 (1987) nr 1-2, s. 79-81. 
chrześcijańskiej najpierw chrztu, a następnie komunii św. Osoba dopiero co ochrzczona - także w wypadku tej, która osiągnęła już wiek umożliwiający świadome popełnienie grzechu ciężkiego - nie potrzebowała spowiedzi, aby przyjąć pierwszą komunię św. $.^{30} \mathrm{Grze}-$ chy gładził bowiem dopiero co przyjęty chrzest św. Sytuacja uległa jednak zmianie, gdy pierwszą komunię św. odsunięto od chrztu do czasu osiągnięcia tzw. lat rozeznania.

Używając pojęcia anni discretionis, ojcowie soborowi nie dookreślili niestety, o jaki wiek chodzi, co spowodowało, że w następnych stuleciach wyrażenie to interpretowano różnie. Wśród współczesnych nam badaczy tematu odnajdziemy takich, którzy uważają, że kanoniści okresu Soboru Laterańskiego IV utrzymywali, jakoby w stosunku do spowiedzi wiek rozeznania mógł się różnić od wieku właściwego dla przyjęcia pierwszej komunii św. ${ }^{31}$ Dominuje jednak przekonanie, że trzynastowieczni kanoniści, i w zgodzie z nimi ojcowe soboru, używając pojęcia anni discretionis, wskazywali na ten sam wiek, zarówno gdy nauczali o konieczność przystąpienia do pierwszej spowiedzi, jaki i komunii św. Chodziło zaś o taki poziom rozwoju człowieka, w którym jest on już w stanie odróżnić dobro od zła i ze świadomością czynionego zła popełnić grzech (czyli jak wówczas mówiono jest doli capax). Doktryna kanonistyczna współczesna Soborowi Laterańskiemu IV wiek ten określała na poziomie 7 roku życia. Zgodnie z taką interpretacją soborowego anni discretionis, od 7 roku życia

30 Por. M. Pastuszko, Uczestnictwo..., dz. cyt., s. 42.

31 Por. J. Szczepański, Praktyka pierwszej komunii dzieci w Kościele na Zachodzie i w Polsce. Studium historyczno-pastoralne, Marki 1999, s. 26. Na temat wieku właściwego do pierwszej komunii św. z perspektywy Soboru Laterańskiego IV zob. także: J. Ernst, Die Zeit der ersten hl. Kommunion und die Jahre der Unterscheidung seir dem IV Konzil vom Lateran, „Archiv für katholisches Kirchenrecht” 107 (1927), s. 433-497; J. Ernst, Um die Zeit der ersten hl. Kommunion, „Archiv für katholisches Kirchenrecht" 109 (1929), s. 594-598. 
dziecko nie tylko mogło, ale wręcz miało obowiązek przyjęcia komunii św. w okresie Świąt Wielkiej Nocy.

Po soborze dogłębnej analizy pojęcia „lata rozeznania” podjęli się liczni teolodzy ${ }^{32}$. Paladarus, profesor teologii w Paryżu z początków XIV wieku, nie oddzielał wieku właściwego do przyjęcia wspomnianych dwóch sakramentów ${ }^{33}$. Piotr Aureoli34, trzynastowieczny profesor teologii na Uniwersytecie w Paryżu, w swoich komentarzach do Sentencji Piotra Lombarda, także nie rozdzielając rozeznania właściwego spowiedzi i odpowiedniego do przystąpienia do pierwszej komunii św., utrzymywał jednak, iż jedno dziecko może osiągnąć anni discretionis już w wieku 7 lat, inne dopiero mając lat $9^{35}$.

Równocześnie ze wspomnianymi wyżej teologami działali inni, reprezentujący pogląd o konieczności głębszego rozeznania do przyjęcia pierwszej komunii św. niż do pierwszej spowiedzi; i wraz z upływem czasu ta właśnie opinia zyskiwała coraz więcej zwolenników. Święty Albert Wielki (zm. 128o) utrzymywał, że ze względu na szacunek, jakim winno się obdarzać Eucharystię, nie należy dopuszczać do niej niektórych osób, w pierwszym rzędzie dzieci. Dopiero po osiągnięciu przez nie wieku 10-12 lat i nabyciu umiejętności rozróżnienia między zwykłym chlebem a jego

32 Por. J. Szczepański, Pierwsza komunia..., dz. cyt., s. 33-34.

33 Por. P. Browe, Die Pflichtkommunion in Mittelalter, Münster 1940, s. 157.

34 Petrus Aureoli (ur. ok. 128o, zm. 22.01.1322): francuski teolog i filozof, w scholastycznych tekstach określany mianem Doctor Facundus. Nauczał w Bolonii, Tuluzie, na uniwersytecie w Paryżu. Jest autorem komentarza do Sentencji Piotra Lombarda. Komentarz ten ukazał się drukiem w Rzymie w 1596 roku i był używany aż do czasów nowożytnych. Przedmiotem swoich badań uczynił on m.in. ludzkie poznanie otaczającej nas rzeczywistości. Zob. m.in.: J. Krokos, Odsłanianie intencjonalności, Stare Kościeliska 2013, s. 127-132.

35 Commentarius in IV. libros „Sententiarum” Petri Lombardi: critice edita a Nazareno Mariani, Grottaferrata (Roma) 2003, d.2, q.2. 
postacią eucharystyczną mogą one przyjmować komunię św. ${ }^{36}$ Zbliżony do powyższego pogląd reprezentował także św. Tomasz z Akwinu (zm. 1247). Od chcących przyjąć komunię św. domagał się, aby potrafili rozróżnić pokarm dla ciała i pokarm duchowy oraz aby cechowała ich „pobożność aktualna”. Stan taki, zdaniem Akwinaty, można osiągnąć około 10-11 roku życia. Opinię tę podzieliła z czasem większość teologów średniowiecza ${ }^{37}$, co doprowadziło w XIV wieku do powstania praktyki przystępowania dzieci do pierwszej spowiedzi nawet kilka lat wcześniej niż do pierwszej komunii św. ${ }^{38}$

Po utrwaleniu się takiej praktyki, żyjący na przełomie XVI i XVII wieku Franciszek Suarez interpretował konstytucję 21 Soboru Laterańskiego IV w duchu powszechnie panującego wówczas zwyczaju. Podkreślał, że dziecko używające rozumu, a więc zdolne do popełnienia grzechu ciężkiego, zobowiązane jest do corocznej spowiedzi św. Używanie rozumu umożliwiające odróżnienie dobra od zła nie jest jednak równoznaczne - zdaniem Suareza z osiągnięciem rozeznania wymaganego do przyjęcia komunii św., co w wypadku dzieci powyżej 7 roku życia skutkowało powstaniem obowiązku corocznej spowiedzi bez obowiązku przyjmowania komunii św. wielkanocnej39.

Analizując z kolei źródła dokumentujące nauczanie synodów, od Soboru Laterańskiego IV do Soboru Trydenckiego można zauważyć, że - podobnie jak w wypadku teologów i kanonistów

36 Por. J. Szczepański, Pierwsza komunia..., dz. cyt., s. 34-35.

37 Utrzymywano, że jeszcze przed 14 rokiem życia trudno spodziewać się, aby dziecko potrafiło pojąć różnicę między zwykłym chlebem a chlebem konsekrowanym. Zob. J. Szczepański, Praktyka pierwszej..., dz. cyt., s. 28.

38 W xıII wieku kanoniści i teolodzy o powyższej praktyce jeszcze nie wspominają. Zob. F. Gillmann, Zur Frage der „anni discretionis” im Kanon Omnis utriusque sexus, „Archiv für katholisches Kirchenrecht“ 110 (1930), s. 157.

39 Zob. F. Suarez, Commentaria ac disputationes in tertiam partem divi Thomae, Venetiis 1605 , De sacramento Eucharistiae d. 70, sect. 1, n. 3. 
kształtujących ówczesną doktrynę - interpretacja kanonu laterańskiego była bardzo różnorodna. Uogólniając, anni discretionis umiejscawiano, w zależności od konkretnego synodu, między 7 a 14 rokiem życia ${ }^{40}$. Ta różnorodność orzeczeń synodalnych w praktyce duszpasterskiej skutkowała dopuszczaniem do przyjęcia pierwszej komunii św. dzieci częściej między 10 a 14 rokiem życia niż w wieku 7 czy 8 lat.

Wprowadzenie w życie konstytucji 21 Soboru Laterańskiego IV zaowocowało rozciągnięciem w czasie przygotowywania dzieci do pełnego uczestnictwa w Eucharystii. Ciężar rzeczonego przygotowania w okresie przedtrydenckim w praktyce spoczął na rodzicach naturalnych i chrzestnych dziecka. Kościół w swoim wymiarze instytucjonalno-hierarchicznym służył wspomnianym osobom pomocą m.in. poprzez określenie wiedzy koniecznej do przyjęcia pierwszej komunii św. Wyraźny rozwój w zakresie katechizacji dzieci dostrzec można jednak dopiero po Soborze Trydenckim. Jego rozporządzenia, uzupełnione następnie przez papieża św. Piusa X w zakresie anni discretionis realizowane są w duszpasterstwie do dnia dzisiejszego ${ }^{41}$.

Sobór Trydencki także nie doprecyzował, które lata życia należy uznać za „lata rozeznania” wystarczającego do przyjęcia pierwszej komunii św. Nie uczynił tego również soborowy katechizm, ograniczający się do stwierdzenia, że ocena w powyższej kwestii należy do ojca dziecka i do spowiednika. W nauczaniu soborowym podkreślono natomiast rolę przygotowania dziecka do pełnego uczestnictwa w Eucharystii. Na pierwszym miejscu sobór nakazywał proboszczom lub ich zastępcom głoszenie nauk w zakresie prawd wiary, a także wad i cnót człowieka, tj. w zakresie wiedzy

40 Por. J. Szczepański, Pierwsza komunia..., dz. cyt., s. 36.

41 Por. J. Szczepański, Pierwsza komunia..., dz. cyt., s. 44-45. 
powiązanej ze zbawieniem człowieka. Mieli to czynić w każdą niedzielę i święta ${ }^{42}$.

Część ojców soborowych zaproponowała ponadto opracowanie katechizmu dla dzieci i ludzi prostych. W kwietniu 1546 roku debatowano nawet nad projektem dekretu, mocą którego takowy katechizm miałby wejść w użycie. I pomimo że dekretu tego ostatecznie nie uchwalono, wspomniana idea przyczyniła się do powstania w czasie trwania soboru wielu katechizmów dla dorosłych i dla dzieci, z których to najbardziej rozpowszechnionym stał się z czasem katechizm św. Piotra Kanizjusza ${ }^{43}$. Soborowa idea katechizmu, już po zamknięciu obrad, zaowocowała powołaniem do życia przez papieża Piusa IV komisji ds. katechizmu pod przewodnictwem św. Karola Boromeusza. Catechismus ex decreto Concilii Tridentini iussu editus, popularnie zwany Katechizmem rzymskim ukazał się w 1566 roku, za pontyfikatu papieża Piusa v.

Katechizmy używane były w nauczaniu dzieci i młodzieży zarówno przez nauczających, jak i uczących się. Oprócz wspomnianych wyżej, w poszczególnych krajach redagowano i wydawano kolejne. Dla przykładu we Francji Edmond Auger wydał zmodyfikowany do tamtych właśnie uwarunkowań pastoralnych katechizm Kanizjusza. We Włoszech, na polecenie papieża Klemensa VIII katechizm opracował kardynał Robert Bellarmin. Dzieło to tłumaczone było na ponad 50 języków (w tym także na język polski) i doczekało się ponad 400 wydań ${ }^{44}$. W Hiszpanii

42 Por. J. Szczepański, Pierwsza komunia..., dz. cyt., s. 45.

43 Piotr Kanizjusz był autorem trzech katechizmów. Pierwszy - zwany wielkim - powstały w 1555 roku, przeznaczony był dla studentów teologii i duszpasterzy. Drugi, którego odbiorcami mieli być ludzie prości, powstał rok później. Trzeci, z 1559 roku, zatytułowany Parvus catechismus catholicorum, najbardziej popularny spośród trzech wymienionych, napisany został dla użytku uczącej się młodzieży.

44 Robert Bellarmin był autorem dwóch różnych katechizmów: większego i mniejszego. Oba w polskiej wersji językowej zostały wydane kilka lat temu przez krakowskie wydawnictwo Ultramontes. Zob. Robert kard. Bellarmin, Wykład nauki 
na przełomie XVI i XVII wieku o. Gaspar Astete zredagował Catecismo de la Doctrina Cristiana, który tłumaczono następnie na kastylijski, baskijski, włoski i języki używane na Filipinach ${ }^{45}$. W 1591 roku także w Hiszpanii wydano drugi katechizm, którego autorem był Jerónimo Martínez de Ripalda ${ }^{46}$. Oba hiszpańskie katechizmy przetłumaczone zostały z czasem na języki Indian w hiszpańskich koloniach Ameryki. Katechizmy te obecne były w duszpasterstwie języka hiszpańskiego i kształtowały podstawy wiedzy religijnej do czasów Soboru Watykańskiego II.

Biorąc powyższe pod uwagę, należy stwierdzić, że nie determinując w dalszym ciągu konkretnego wieku dziecka wymaganego do przyjęcia pierwszej komunii św., Sobór Trydencki dokonał jednak zasadniczej zmiany w procesie przygotowania osób pragnących w pełni uczestniczyć w Eucharystii. Odtąd przyjęcie pierwszej komunii musiała poprzedzać obowiązkowa katechizacja, której podstawowy ciężar spoczął na duszpasterzach. Mieli oni nie tyle współpracować z rodzicami i chrzestnymi (na których to do Soboru Trydenckiego spoczywał ciężar przygotowania dziecka do pierwszej komunii), ile przejąć zasadniczą cześć przygotowania związaną z przekazaniem wiedzy koniecznej.

chrześcijańskiej ułożony z rozkazu Klemensa VIII papieża, Kraków 2015; Robert kard. Bellarmin, Katechizm mniejszy, czyli nauka chrześcijańska krótko zebrana i ułożona z rozkazu Klemensa viı papieża, Kraków 2013.

45 Katechizm o. Gaspara Astetego doczekał się wielu wydań także w koloniach, a potem niepodległych krajach Ameryki Łacińskiej. Zob. m.in.: Catecismo de la doctrina cristiana del padre Gaspar Astete corregido i mejorado para uso de las parroquias de la arquidiócesis de Bogota, Bogota 1854.

46 Pierwsze wydanie katechizmu Ripaldy ukazało się w Burgos w 1591 roku; drugie (bardziej rozpowszechnione) ukazało się w Toledo w 1618 roku i doczekało się wielu kolejnych wydań. Zob. m.in.: Catecismo y exposición breve de la Doctrina Cristiana compuesto por el P. Jerónimo de Ripalda de la Compañía de Jesús, Barcelona 1880 . 
Krótko po soborze wspomniany już tutaj jezuita Franciszek Suarez pisał, że nie da się jednoznacznie wyznaczyć wieku, w którym dzieci zobowiązane byłyby do przyjęcia komunii św. Podaje natomiast, że niektórzy teologowie przesuwają wspomnianą granicę wiekową do 14, a nawet 15 roku życia ${ }^{47}$. Święty Alfons Liguori, osiemnastowieczny biskup i wybitny moralista uważał, że nie ma podstaw, aby - z jednej strony - zobowiązywać dzieci do przyjmowania Eucharystii przed 9-10 rokiem życia, z drugiej, w wypadku normalnie rozwiniętych umysłowo i emocjonalnie dzieci nie należy przesuwać granicy pełnego uczestnictwa w Eucharystii powyżej 12, a tym bardziej poza 14 rok życia ${ }^{48}$.

Wspomniani wyżej autorzy stanowią odbicie dominującej w okresie potrydenckim praktyki duszpasterskiej zmierzającej do zawyżania wieku dzieci dopuszczanych do pierwszej komunii św. Tendencję tą obrazuje m.in. ustawa synodu w Kolonii z 1662 roku, nakazująca duszpasterzom uświadamiać wiernym, iż niewskazanym jest przesuwanie przyjęcia pierwszej komunii św. do 16 roku życia czy też do momentu zawierania małżeństwa ${ }^{49}$. Na przesuwanie wieku na coraz wyższy w XVIII i XIX wieku wpłynął jansenizm, nurt teologiczny wywodzący się od Korneliusa Jansena. Janseniści utrzymywali bowiem, że Komunia św. jest nagrodą za dobre życie, nie zaś lekarstwem na ułomność ludzką. Należy więc przyjmować ją raczej rzadko, i to pod warunkiem spełnienia wielu wymagań ${ }^{\circ}$.

47 Zob. F. Suarez, Commentaria ac disputationes in tertiam partem s. Thomae, De sacramento Eucharistiae et de Missae sacrificio, d. 70, sect. 1, n. 4.

48 Zob. Theologia moralis illustrissimi ac reverendissimi D. Alphonsi de Ligorio, Matriti 1829-1830, lib. 6, tract. 3, cap. 2, n. 3.

49 Por. J. Szczepański, Pierwsza komunia..., dz. cyt., s. 52.

50 Jansenizm pojawił się w XVII i XVIII wieku w Niderlandach, rozprzestrzenił się we Francji. Uważany był dosyć powszechnie za fundament doktryny reformatorów oświeceniowych. Zob. W. J. Collahan, D. Higgis, Church and Society in Catholic Europe of Eighteenth Century, Cambridge 1979, s. 8. 


\section{Dekret Świętej Kongregacji Sakramentów Quam singulari z 8 sierpnia 1910 roku}

Tendencja odwrotna do wspomnianej wyżej pojawiła się dopiero w XIX wieku, w którym to m.in. w oparciu o nauki historyczne wskazywano na wcześniejszą praktykę Kościoła. Ta odmienna perspektywa, za przyczyną Piusa x w początkach xx wieku znalazła swoje odzwierciedlenie w nowych regulacjach prawa kanonicznego ${ }^{51}$. W grudniu 1905 roku papież zatwierdził dekret Świętej Kongregacji Soboru Sacra Tridentina Synodus o codziennej komunii św..$^{22} \mathrm{~W}$ sierpniu 1910 roku zatwierdził z kolei dekret Świętej Kongregacji Sakramentów Quam singulari Christus amore o wczesnym dopuszczeniu dzieci do pierwszej komunii św. 53

We wspomnianym dekrecie z 8 sierpnia 1910 roku wyróżnić można dwie części: historyczno-teoretyczną i praktyczną. W pierwszej prawodawca przywołał praktykę udzielania do XIII wieku pierwszej komunii św. dzieciom bezpośrednio po przyjęciu chrztu św., aby następnie wskazać na zasadniczą zmianę, jakiej w powyższym zakresie dokonał Sobór Laterański IV, nakazujący „wszystkim wiernym, po dojściu do używania rozumu, spowiedź

51 Por. J. J. Janicki, Święty Pius x (1903-1914) - papież Eucharystii, „Kieleckie Studia Teologiczne" 10 (2011), s. 191-213.

52 S. Congregatione Concilii, Decretum De dispositionibus requisitis ad frequentem et quotidianam Communionem eucharisticam sumendam, „Acta Sanctae Sedis” [dalej: Ass] 38 (1905), s. 400-404. Tekst polski w: Eucharystia w wypowiedziach papieży i innych dokumentach Stolicy Apostolskiej XX w., red. R. Rak, Londyn 1987, s. 31-36. Zgodnie z wspomnianym wyżej dekretem wszyscy wierni mogą często, a nawet codziennie przystępować do komunii św. pod warunkiem, że ich sumienie nie jest obciążone grzechem ciężkim i że przyjmują oni komunię z dobrą intencją, tj. aby podobać się Bogu, a nie ze zwyczaju, próżności czy przyzwyczajenia. Por. M. Pastuszko, Uczestnictwo..., dz. cyt., s. 48.

53 S. Congregatio de Sacramentis, Decretum De aetate admittendorum ad primam communionem eucharisticam, „Acta Apostolicae Sedis” [dalej: AAs] 2 (1910), s. 577-583. Tekst polski w: Eucharystia w wypowiedziach..., dz. cyt., s. $37 \mathrm{nn}$. 
i Komunię świętą" ${ }^{4}$. Wskazując, że sobór ten „wymaga jednego i tego samego wieku rozeznania" dla spowiedzi i komunii św., dekret mówił o „wielu błędach”, jakie pojawiły się na przestrzeni wieków w interpretacji wieku rozeznania. Kongregacja „za odpowiedni do przyjęcia komunii św. z należną pobożnością uważa wiek, w którym dziecko chleb eucharystyczny od chleba zwykłego materialnego umie odróżnić”. Do przyjęcia pierwszej komunii nie wymaga więc pełnego używania rozumu ani pełnej znajomości prawd wiary.

W oparciu o zawarte w części historyczno-teoretycznej założenia Kongregacja w części drugiej wprowadziła bardziej szczegółowe zalecenia, ujmując je w ośmiu punktach. Na szczególną uwagę zasługuje w tym miejsce pierwszy z nich, w którym stwierdza się: „Wiekiem rozeznania tak co do spowiedzi, jak i co do Komunii jest wiek, w którym dziecko zaczyna rozumować, czyli mniej więcej rok siódmy, niekiedy nieco później, niekiedy nawet wcześniej. Od tego czasu zaczyna obowiązywać dziecko przykazanie dotyczące spowiedzi i Komunii świętej” ${ }^{55}$. W ten sposób po siedmiu

54 Eucharystia w wypowiedziach..., dz. cyt., s. 38.

55 Pozostałe siedem punktów: „2. Do pierwszej spowiedzi i do pierwszej Komunii świętej nie jest konieczna pełna i doskonała znajomość nauki chrześcijańskiej. Dziecko powinno wyuczyć się całego katechizmu stopniowo, odpowiednio do swej pojętności. 3. Znajomość zasad religii, potrzebna dziecku do odpowiedniego przygotowania się do pierwszej Komunii świętej ma być taka, by dziecko stosownie do swego rozwoju umysłowego przyswoiło sobie prawdy wiary konieczne do zbawienia i, odróżniając Chleb eucharystyczny od zwykłego i ziemskiego chleba, mogło przystąpić do Najświętszej Eucharystii z pobożnością, na jaką je w jego wieku stać. 4. Troska o to, by dziecko wypełniło ciążący na nim obowiązek, dotyczący przykazania o spowiedzi i Komunii, spada głównie na jego opiekunów, a więc na rodziców, na spowiednika, na nauczyciela i na proboszcza. Do rodziców zaś i ich zastępców oraz do spowiednika należy, według Katechizmu Rzymskiego, dopuszczanie dziecka do pierwszej Komunii świętej. 5. Raz lub więcej razy w roku niech proboszczowie zapowiedzą i urządzą generalną Komunię dzieci i dopuszczą do niej nie tylko te dzieci, które dopiero pierwszy raz komunikują, lecz także i te, które jak 
wiekach, które upłynęły od Soboru Laterańskiego IV, dekretem Quam singulari prawodawca dookreślił wiek rozeznania dziecka na poziomie siedmiu lat. Wszelkie wcześniejsze opinie doktryny kanonicznej nabrały znaczenia historycznego, a niezgodne z zapisem dekretu uchwały synodów utraciły moc obowiązującą.

Początkową reakcją na dekret była jednak nie tyle powszechna aprobata, ile raczej obawy związane ze zmianami, jakie nieuchronnie niósł on w zakresie dotychczasowej praktyki duszpasterskiej (w tym także w Kościele katolickim w Polsce rozbiorowej i w II Rzeczpospolitej) $)^{5}$. Pomimo oczekiwań wielu, wychowanych w duchu wielowiekowej praktyki udzielania pierwszej

było wyżej powiedziane, za zgodą rodziców lub spowiednika, już przedtem po raz pierwszy przystąpiły do Stołu Pańskiego. Jedne i drugie dzieci należy wpierw przez parę dni pouczyć i przygotować.6. Sprawujący opiekę nad dziećmi powinni dołożyć wszelkich starań, by dzieci po pierwszej Komunii świętej przystępowały do Stołu Pańskiego częściej, a nawet, o ile to jest możliwe, codziennie, jak tego pragnie Jezus Chrystus i Kościół święty, Matka nasza i by przystępowały z taką pobożnością, na jaką dzieci w ich wieku stać. Ci też opiekunowie powinni nadto pamiętać o nader poważnym obowiązku czuwania nad tym, aby dzieci, które przyjęły pierwszą Komunię świętą, uczęszczały potem w dalszym ciągu na publiczną naukę religii. Jeżeli zaś nie jest to możliwe, niech w inny sposób udostępnią dzieciom gruntowniejszą naukę religii. 7. Stanowczo należy potępić zwyczaj niedopuszczania do spowiedzi dzieci, które doszły już do używania rozumu lub spowiadania ich, ale bez rozgrzeszenia. Biskupi winni dołożyć starań, a nawet użyć środków. 8. Z oburzeniem napiętnować trzeba nadużycie, że dzieci, które doszły do używania rozumu, nie zaopatruje się w niebezpieczeństwie śmierci świętym Wiatykiem i Ostatnim Namaszczeniem. Biskupi powinni wystąpić z całą surowością przeciwko tym, którzy takiego zwyczaju wyzbyć się nie chcą. Powyższą uchwałę Kardynałów, należących do tej świętej Kongregacji, Ojciec święty Pius x na posłuchaniu dnia 7 tego miesiąca w całości zatwierdził i kazał dekret niniejszy wydać i ogłosić. Nadto polecił wszystkim biskupom, żeby tenże dekret podali do wiadomości nie tylko proboszczom i w ogóle duchowieństwu, lecz także wiernym, i zarządził, aby corocznie w okresie spowiedzi wielkanocnej odczytywano go wiernym w języku ojczystym" (Eucharystia w wypowiedziach..., dz. cyt., s. 43-44).

56 Por. J. Salij, Główne kontrowersje..., dz. cyt., s. $190 \mathrm{nn}$. 
komunii św. w późniejszym wieku ${ }^{57}$, za pontyfikatu papieża Benedykta XV podtrzymano jednak w mocy zapisy dekretu z 8 sierpnia $1910 \mathrm{roku}^{58}$.

\section{Przepisy dotyczące przyjęcia pierwszej komunii św. w kodeksach prawa kanonicznego z 1917 i 1983 roku}

Cytowana wyżej norma dekretu Quam singulari znalazła swoje odzwierciedlenie zarówno w Kodeksie prawa kanonicznego z 1917 roku (kan. 88 § 3), jak i w Kodeksie prawa kanonicznego z 1983 roku (kan. 97 § 2). Zgodnie z przytoczonymi kanonami obu kodeksów po ukończeniu 7 roku życia dziecko uważa się za używające rozumu ${ }^{59}$.

Według kan. 854 Kodeksu prawa kanonicznego z 1917 roku do pierwszej komunii św. może być dopuszczona osoba posiadająca rozeznanie oraz znajomość głównych prawd wiary. Nie należy więc dopuszczać do przyjęcia komunii św. tych, którzy nie ukończyli 7 roku życia (tj. „dzieci” w kodeksowym rozumieniu tego terminu) oraz osób z nimi związanych, a także tych, którzy nie posiadają wiedzy co do prawd wiary koniecznych do zbawienia. Decyzja o dopuszczeniu dziecka do pierwszej komunii św. należy

57 Por. J. Szczepański, Pierwsza komunia..., dz. cyt., s. 55.

58 Zob. Benedictus PP. xv, De eucharistica puerorum utriusque sexus Communione ad mentem Summi Pontificis, die 30 mensis iulii sollemni ritu promovenda, AAS 8 (1916), s. 217.

59 Wspomniane wyżej prawne domniemanie iuris tantum dopuszcza dowód przeciwny. Zob. A. de Fuenmayor, Comentario (al canon 97), w: Comentario exegético al Código de Derecho canónico, obra coordinada y dirigida por Á. Marzoa, J. Miras, R. Rodríguez-Ocaña, vol. 1, Pamplona 1983, s. 722. Dopuszczając dowód przeciwny, rzeczone domniemanie pozostaje w zgodzie z cytowanym zapisem dekretu Quam singulari „Wiekiem rozeznania [...], w którym dziecko zaczyna rozumować, czyli mniej więcej rok siódmy, niekiedy nieco później, niekiedy nawet wcześniej” [tłum. własne]. 
do rodziców lub opiekunów dziecka (w wypadku, gdy rodzice nie wypełniają władzy rodzicielskiej) oraz spowiednika. Proboszcza prawodawca obarcza obowiązkiem dopilnowania, by konkretna osoba nie przystępowała do stołu Pańskiego, nie ciesząc się używaniem rozumu i bez wystarczającego przygotowania.

Mniejsze wymagania kodeks z 1917 roku stawia osobom, które nie przyjęły jeszcze pierwszej komunii św., a znalazły się w niebezpieczeństwie śmierci (periculum mortis). W sytuacji tej wymaga się od przyjmującego tylko umiejętności odróżnienia zwykłego chleba od eucharystycznego i przyjęcia go z należną czcią (kan. 854 § 2) ${ }^{60}$.

Pomijając samo sformułowanie słowne przepisów zawartych w kan. 854 §§ 1-5 kodeksu Pio-Benedyktyńskiego, treść obowiązujących obecnie regulacji kodeksowych w powyższym zakresie (kan. 913 i 914) nie uległa znaczącym zmianom. W kan. 913 § 1 Kodeksu prawa kanonicznego z 1983 roku czytamy: „Dzieci wtedy można dopuścić do Komunii świętej, gdy posiadają wystarczające rozeznanie i są dokładnie przygotowane, tak by stosownie do swojej możliwości rozumiały tajemnicę Chrystusa oraz mogły z wiarą i pobożnością przyjąć Ciało Chrystusa”. Z kolei w kan. 913 § 2 prawodawca stwierdza: „Jednakże dzieciom znajdującym się w niebezpieczeństwie śmierci wolno udzielić Najświętszej Eucharystii, gdy potrafią odróżnić Ciało Chrystusa od zwykłego chleba i mogą z szacunkiem przyjąć Komunię świętą" ${ }^{\text {. }}$

Zgodnie z kan. 914 kodeksu z 1983 roku „Jest przede wszystkim obowiązkiem rodziców oraz tych, którzy ich zastępują, jak również proboszcza troszczyć się, ażeby dzieci, po dojściu do używania

6o Por. F. Bączkowicz, Prawo kanoniczne. Podręcznik dla duchowieństwa, t. 2, Opole 1958, s. 36-37.

61 Podobnie jak w kan. 854 § 2 Kodeksu prawa kanonicznego z 1917 roku, tak i w kan. 913 § 2 kodeksu obecnie obowiązującego prawodawca mówi o niebezpieczeństwie śmierci (periculum mortis), a nie o sytuacji śmierci nieuchronnej. 
rozumu, zostały odpowiednio przygotowane i jak najszybciej posiliły się tym Bożym pokarmem, po uprzedniej sakramentalnej spowiedzi. Do proboszcza należy również czuwać nad tym, by do Stołu Pańskiego nie dopuszczać dzieci, które nie osiągnęły używania rozumu albo jego zdaniem nie są wystarczająco przygotowane”.

W sytuacji niezwiązanej z niebezpieczeństwem śmierci - zgodnie z kan. 913 - od dziecka mającego przyjąć pierwszą komunię św. wymaga się więc używania rozumu na poziomie umożliwiającym nabycie rozeznania, które to w połączeniu z właściwym przygotowaniem pozwoli zrozumieć „tajemnicę Chrystusa” i przyjąć z wiarą chleb eucharystyczny ${ }^{62}$. Kryterium decydującym o powstaniu obowiązku wspomnianego przygotowania jest nie tyle ukończenie 7 roku życia, uważane w prawie za wiek dojścia do używania rozumu, ile rzeczywiste nabycie używania rozumu przez konkretną osobę. Przygotowanie takiej osoby do przyjęcia komunii św. zakłada m.in. katechezę o tajemnicy Boga w Trójcy Jedynego i o tajemnicy wcielenia ${ }^{63}$.

Jednym z etapów poprzedzających, a zarazem przygotowujących do przyjęcia pierwszej komunii św. jest przystąpienie do sakramentalnej spowiedzi ${ }^{64}$. Z powodu wątpliwości, jakie pojawiły

62 Por. I. Gramunt, Comentario (al can. 913), w: Comentario exegético al Código de Derecho canónico, obra coordinada y dirigida por Á. Marzoa, J. Miras, R. Rodríguez-Ocaña, vol. 3, Pamplona 1983, s. 624.

63 Por. E. Górecki, Najświętsza Eucharystia..., dz. cyt., s. 99. Zgodnie z kan. 775 § 1, zachowując przepisy wydane przez Stolicę Apostolską w powyższej kwestii, do biskupa diecezjalnego należy wydanie norm dotyczących katechezy, w tym również katechezy dla dzieci przygotowujących się do pierwszej komunii św., a także wspieranie i koordynacja poczynań katechetycznych.

64 Kanon 914 postanawia, że wcześniejsza w stosunku do pierwszej komunii św. spowiedź sakramentalna stanowi przygotowanie do przyjęcia komunii św. Wspomniany przepis kanonu winien znaleźć swoje odzwierciedlenie w praktyce pastoralnej związanej z przygotowaniem dziecka do przyjęcia pierwszej komunii. Zob. J. D. Gandía, Primera comunión, w: Diccionario general de derecho 
się w tym zakresie po Soborze Watykańskim II, a także praktyki udzielania pierwszej komunii św. bez wcześniejszej spowiedzi sakramentalnej w niektórych Kościołach lokalnych, konieczność przystąpienia do spowiedzi przed przyjęciem pierwszej komunii potwierdziła deklaracja Kongregacji Sakramentów i Kongregacji Duchowieństwa z 24 maja 1973 roku ${ }^{65}$. Biorąc pod uwagę powyższą konieczność, katecheza dziecka winna objąć także tematy dotyczące sakramentu pokuty, grzechu, stanu łaski uświęcającej.

Odpowiedzialnymi za wspomniane przygotowanie kan. 914 czyni w pierwszym rzędzie rodziców naturalnych dziecka - a jeśli tych brak lub nie mogą wypełniać tego zadania - osoby, które ich zastępują, tj. prawnych opiekunów, rodziców chrzestnych, krewnych. Odpowiedzialnym za przygotowanie rzeczony kanon czyni także proboszcza, w wymiarze mu właściwym. Dlatego kan. 776

canónico, obra coordinada y dirigida por J. Otaduy, A. Viana, J. Sedano, vol. 6, Pamplona 2012, s. 458.

65 Po Soborze Watykańskim II pojawiła się opinia, jakoby dzieci cieszące się od niedawna używaniem rozumu zwykle nie miały jeszcze na sumieniu grzechu ciężkiego i ze względu na to nie potrzebowały spowiedzi sakramentalnej przed pierwszym przystąpieniem do komunii św. W ogólnym Dyrektorium katechetycznym z 11 kwietnia 1971 roku przyznano nawet, że Stolica Apostolska zezwoliła niektórym Kościołom partykularnym na dopuszczanie dzieci do pierwszej komunii św. bez wcześniejszego przystąpienia do spowiedzi. Zob. M. Pastuszko, Chrześcijanin jako penitent (kanony 987-991), „Prawo Kanoniczne” 39 (1996) nr 3-4, s. 141. Salij wspomina o próbach udzielania pierwszej komunii św. bez wcześniejszej spowiedzi w Kościele holenderskim. Zob. J. Salij, Główne kontrowersje teologiczne..., dz. cyt., s. 219, przypis 152.

24 maja 1973 roku wspomniane wyżej Kongregacje (Sakramentów i Duchowieństwa) wydały wspólną deklarację odwołującą wcześniejsze zezwolenie na rzeczoną praktykę i nakazały powrót do dyscypliny z dekretu Quam singulari, tj. odbycie spowiedzi przed pierwszą komunią św. Zob. Sacra Congregatio De Disciplina Sacramentorum et Sacra Congregatio Pro Clericis, Declaratio de praemittendo sacramento Poenitentiae primae puerorum Communioni, AAs 65 (1973), s. 410. Zob. także: Responsum ad propositum dubium, 27 maii 1977 Sacrae Congregationis pro Sacramentis et Cultu Divino atque pro Clericis, AAs 69 (1977), s. 427. 
stwierdza: „Do proboszcza należy popierać i umacniać zadanie rodziców w zakresie katechezy rodzinnej, o której w kan. 774 § 2". Z kolei w kan. 777, nr 2 i 4 prawodawca stwierdza: „Uwzględniając normy wydane przez biskupa diecezjalnego, proboszcz ma w szczególny sposób troszczyć się [...] aby dzieci, przez nauczanie katechetyczne trwające odpowiedni czas, zostały właściwie przygotowane do pierwszego przyjęcia sakramentów pokuty i Najświętszej Eucharystii” i aby „katechizować także upośledzonych fizycznie i umysłowo, na ile pozwala na to ich stan"66.

W konsekwencji, do obowiązków proboszcza należy czuwanie „nad tym, by do Stołu Pańskiego nie dopuszczać dzieci, które nie osiągnęły używania rozumu albo jego zdaniem nie są wystarczająco przygotowane”. Ocena wystarczającego poziomu przygotowania należy więc do niego. W porównaniu z kan. 854 § 4 Kodeksu prawa kanonicznego z 1917 roku z powyższego obowiązku zwolniony został spowiednik dziecka ${ }^{67}$. Zdarza się - jak zauważa Marian Pastuszko ${ }^{68}$ - że rodzice nie zgadzają się z opinią proboszcza, który nie chce dopuścić dziecka do pierwszej komunii św., a decyzję argumentuje niewystarczającym używaniem rozumu czy niewystarczającym przygotowaniem dziecka. Chodzi m.in. o dzieci nierozwinięte umysłowo w taki sposób, aby używały rozumu wystarczająco do osiągnięcia właściwego rozeznania i przygotowania się do pierwszej komunii w sposób, o którym mowa w kan. 913-914 ${ }^{69}$.

66 J. D. Gandía, Primera comunión..., dz. cyt., s. 461.

67 Wspomniany wyżej przepis kodeksowy (kan. 854 § 4) nie precyzował, kto w sytuacji, gdy proboszcz i spowiednik dziecka mieli odmienne zdanie co do wystarczalności jego przygotowania - decyduje ostatecznie o dopuszczeniu dziecka do przyjęcia pierwszej komunii św.

68 Por. M. Pastuszko, Uczestnictwo w Najświętszej..., dz. cyt., s. 52-53.

69 Por. M. Pastuszko, Uczestnictwo w Najświętszej..., dz. cyt., s. 50-51. 
Omawiając kryteria dopuszczenia do pierwszej komunii św., należy w końcu wspomnieć o tych, które stawiane są dzieciom w niebezpieczeństwie śmierci ( $k a n .913 \S 2$ ). W takiej sytuacji prawodawca wymaga takiego używania rozumu i wiedzy, które umożliwiają dziecku odróżnienie Ciała Chrystusa od zwykłego chleba. Na płaszczyźnie dyspozycji moralnej domaga się z kolei, aby dziecko było zdolne „z szacunkiem przyjąć Komunię świętą”. Jak pisze Ignatius Gramunt, należy założyć, że skoro dziecko dostrzega różnicę między zwykłym chlebem i Chlebem Eucharystycznym, komunię św. przyjmie ono z szacunkiem; chyba że konkretny fakt (a nie tylko subiektywna wątpliwość) wskazuje w wyraźny sposób na coś przeciwnego ${ }^{70}$.

\section{STRESZCZENIE}

\section{Kryteria dopuszczenia dzieci do pierwszej komunii św.}

Tematem artykułu są kryteria dopuszczenia dzieci do pierwszej komunii św. Autor artykułu - zgodnie z starożytną regułą ex nihilo nihil fit - nie ogranicza się do omówienia obowiązujących obecnie regulacji KPK z 1983 roku w powyższej kwestii, ale stara się przeanalizować historyczne źródła obowiązujących dzisiaj przepisów. Całość artykułu podzielona została na cztery części. Pierwsza omawia okres pierwszych dwunastu stuleci. Dominowała w tym czasie praktyka udzielania komunii św. chrzcielnej, czyli przyjmowania Ciała Eucharystycznego - zarówno przez małe dzieci,

70 Por. I. Gramunt, Comentario (al can. 913)..., dz. cyt., s. 624-625. Zob. także: Sacra Congregatio Pro Clericis, Directorium catechisticum generale, Addendum 2, AAS 64 (1972), s. 173. 
jak i dorosłych - bezpośrednio po chrzcie, razem z bierzmowaniem, jako jednego z trzech sakramentów wtajemniczenia chrześcijańskiego. Praktyka ta przerwana została wraz z wprowadzeniem w życie 21 konstytucji Soboru Laterańskiego IV, w której do przyjęcia pierwszej komunii św. prawodawca domagał się właściwego rozeznania osoby przyjmującej. Doprowadziło to o czym mówi druga cześć artykułu - do przesunięcia na późniejsze lata życia momentu pierwszego przyjęcia komunii św. i powiązania tego wydarzenia z poprzedzającą komunię spowiedzią sakramentalną. Trzecia cześć artykułu omawia dekret Świętej Kongregacji Sakramentów Quam singulari z 8 sierpnia 1910 roku, w którym prawodawca kościelny dookreślił poziom rozeznania konieczny do przyjęcia pierwszej komunii św. na poziomie 7 roku życia. Czwarta, w końcu, analizuje przepisy KPK z 1917 roku, w szczególny zaś sposób KPK z 1983 roku, jako regulacji determinujących obowiązujące obecnie kryteria dopuszczenia dzieci do pierwszej komunii św. Słowa kluczowe: pierwsza komunia św., warunki dopuszczalności do sakramentów

SUMMARY

\section{Criteria for the admission of children to First Holy Communion}

The subject of the article is the criteria for the admission of children to the First Communion. The author of the article - in accordance with the ancient rule ex nihilo nihilo fit - is not limited to a discussion of the current regulations of the Code of Canon Law of 1983 in this matter, but tries to analyze the historical sources of the regulations in force today. The whole article is divided into four parts. The first one discusses the period of the first twelve centuries. At that time the practice of baptismal communion, 
i.e. receiving the Eucharistic Body - both by small children and adults immediately after baptism, together with confirmation, as one of the three sacraments of Christian initiation, dominated. This practice was interrupted with the implementation of the 21 Constitutions of Lateran Council IV, in which, for the adoption of the first communion, the legislator demanded a proper discernment of the person receiving it. This led - as the second part of the article says - to the postponement to later years of life of the moment of the first reception of Holy Communion and the connection of this event with the pre-communion sacramental confession. The third part of the article discusses the decree of the Holy Congregation for the Sacraments Quam singulari of August 8, 1910, in which the ecclesiastical legislator defined the level of discernment necessary to receive the first communion at the level of seven years of age. Finally, the fourth examines the provisions of the 1917 Code of Canon Law and, in particular, of the 1983 Code of Canon Law, as the regulations that determine the criteria currently in force for the admission of children to the first communion of Saint John of God.

Keywords: first communion, conditions for admission to the sacraments

Piotr Ryguła, Kryteria dopuszczenia dzieci do pierwszej komunii św., w: Warunki dopuszczalności do sakramentów, ze szczególnym uwzględnieniem sakramentu matżeństwa, red. Piotr Kroczek, Kraków 2017, s. 43-68 (Annales Canonici Monographiae, 7).

DOI: http://dx.doi.org/10.15633/9788374388153.04 